\title{
Tempos e Espaços
}

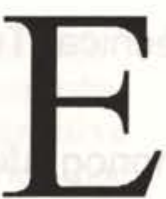

ste número da Revista Travessia, dedicado ao tema " Tempo e Espaço", à primeira vista poderia parecer um mero exercício especulativo, desvinculado da dura realidade da vida dos migrantes.

Trabalhadores do campo e da cidade, teriam lá eles, em sua luta do dia-a-dia pela sobrevivência, disposição, ânimo e condições para preocupar-se com conceitos aparentemente tão abstratos? Pois não só teriam, como realmente o fazem. E à sua maneira, como mostram os diferentes artigos deste número da revista Seja no contexto das grandes metrópoles ou de cidades médias, de povoados litorâneos ou de cidades de fronteira - o que se vê é uma produção constante e diversificada de maneiras de ver, usufruir e dar significado a realidades que erroneamente se supõe serem iguais para todos: o tempo e o espaço.

É impressionante perceber como pessoas absorvidas pelas dificeis condições do cotidiano ( na periferia, na vila, no povoado, no cortiço) constroem - a partir de padrões que ora denotam sua origem rural, ora uma concepção religiosa, ora um ritmo ditado por antigas práticas - medidas de tempo e formas de espaço cheias de significado.

Às vezes, essa elaboração resulta de uma resposta às imposições ditadas pela lógica do trabalho ou da segregação espacial; outras vezes, é a festa que divide e valoriza os tempos, assim em outras circunstâncias é a religião que fornece os padrões.

Seja como for, o que se constata através dos artigos do número 15 de Travessia é a presença de uma dinâmica cultural, rica e diferenciada, que transcende os estreitos limites dos horizontes impostos a seus atores pelas condições de vida e trabalho a que são submetidos.

\section{José Guitherme Cantor Magnani}

